\title{
RE-CLOSED BORDER AS AN EVERYDAY EXPERIENCE. EXPLORATORY RESEARCH OF POLISH-GERMAN TWIN CITIES IN THE FIRST MONTHS OF A COVID-19 PANDEMIC
}

\author{
MACIEJ FRĄCKOWIAK 1 , JERZY KACZMAREK'2, \& ŁUKASZ ROGOWSKI ${ }^{3}$ \\ ${ }^{1}$ Adam Mickiewicz University in Poznań, Szamarzewskiego 89 C, 60-568 Poznań, Poland. ORCID: \\ 0000-0003-3802-1184, Email: maciejf@amu.edu.pl \\ 2 Adam Mickiewicz University in Poznań, Szamarzewskiego 89 C, 60-568 Poznań, Poland. ORCID: \\ 0000-0001-8314-199X, Email: jkaczmar@amu.edu.pl \\ ${ }^{3}$ Adam Mickiewicz University in Poznań, Szamarzewskiego 89 C, 60-568 Poznań, Poland. ORCID: \\ 0000-0001-6090-8975, Email: lukasz.rogowski@amu.edu.pl
}

ABSTRACT: Borders' closure during the COVID-19 pandemic had a particular impact on the everyday life of borderland residents. As part of the research on bordering processes carried out since a few years, during the closure of the state borders in 2020, qualitative interviews on everyday life in the COVID-19 pandemic have been conducted. In this paper, we present the results of the exploratory study on the impact of the COVID-19 pandemic on Polish-German border twin cities. We indicate at what levels borders' closure affected the border landscape, border practices of the inhabitants of the researched territories, and their notion of the border. We also suggest how border relations were shaped due to differences in the management and perception of the pandemic situation in two countries. The results obtained indicate that the closure of borders has made life more difficult in an area under examination and has also affected the identity and specificity of the place. This issue is worth exploring further to establish the true extent of the impact of the pandemic in the borderlands.

KEYWORDS: COVID-19; pandemic; lockdown; border; twin cities; everyday life 


\section{INTRODUCTION}

$\mathrm{O}$ ne of the unexpected consequences of the COVID-19 pandemic was the closure of state borders resulting in the temporary replacement of 'thin borders' by 'thick borders'-restricting the movement of people and goods because of re-establishing control and limiting their ability to cross (Haselsberger 2014: 506), thus reverting the process that had prevailed in Europe after the cold war. Border closures introduced new forms of border control and governmobility, and therefore-in the words of Bærenholdt-how "societies are ruled through connections" (2013: 20). Treating people and goods coming from abroad as potential coronavirus carriers has perpetuated the notion of states as distinct legislative, territorial, and cultural formations that can maintain their independence in a globalized world of flows.

As a result, the closure of borders had significantly changed political and economic relations, but also impacted everyday life. According to Berger and Luckmann (1966), it can be understood as a primary reality where individuals continuously and repetitively fulfil their most crucial needs, including those of a social nature-practices related to self-fulfilment, household maintenance, education, or work. In border areas, such everyday activities often include crossing a border and are accompanied by conversations about the border, taking account of different legal systems, exchanging currency, or being under surveillance by security services. To fully recognize the significance of those daily activities, contemporary border studies refer to them as bordering practices (Scuzzarello \& Kinnavall 2013). This concept helps to see the connections between the different dimensions of bordering: phenomenological (how the individuals experience and negotiate their ideas of the lived world during those activities), political (cross-border integration), and the cultural landscape of the border region (Sohn 2014a).

Implications of changes in everyday routines (and bordering practices) are even more significant in so-called 'twin cities', where many everyday residents' needs are met on the opposite side of the border (Kaczmarek 2001). Twin cities are neighbouring cities having a joint urban layout but divided by the border, often due to historical circumstances. Twin cities are also usually peripheral in terms of their population, location, and economic position for both countries but essential for international cooperation and intercultural integration (Joenniemi 2007: 2). They try to develop their economic foundations and identity not on distinctiveness but of interdependence on their foreign counterparts (Ibid). At the economic, social, and cultural layer, interconnected development has significantly accelerated in central Europe in the last two decades. This phenomenon was mainly due to debordering processes understood as gradual facilitation of cross-border exchange by eliminating some of the material and institutional barriers (Sohn 2014a).

During the pandemic, people in all of Europe have changed their everyday practices, which led to declining quality of life, new ways of performing social roles, and impacting financial situation and plans (Eurofund 2020). However, as can be assumed, this rupture of daily routines and definitions of the situation affected in a specific way the inhabitants of border areas, where it was simultaneously associated with the 
closure of borders. This is the main reason why in this paper we seek to empirically identify the main types of consequences of the COVID-19 pandemic on the border and in the everyday life of people living nearby. The principal question is: how COVID-19 influenced bordering practices and imaginaries of borderlands among its residents. We are focusing on the example of the Polish-German twin cities Gubin/Guben and Słubice/ Frankfurt Oder with the surrounding areas. More specifically, addressing this question seems to be important for two reasons. Firstly, it allows for a better understanding of the social consequences of the pandemic in border areas (especially in twin cities), not only limited to the individual's economic situation but also including identity and sense of place. Secondly, posing such a question can provide findings on bottom-up reactions to border closures and border as an experience, considered substantial for further development of contemporary border studies (Parker \& Vaughan-Williams 2009). The pandemic situation provides an opportunity in this regard. As a crisis, it fosters the reflection and discussions with inhabitants on everyday habits and bottom-up experiences.

\section{PROCESSES OF CLOSING AND OPENING THE POLISH-GERMAN BORDER}

The Polish-German border on the Oder and Lusatian Neisse was marked as a result of the changes after World War II. The first 25 years after the war was called 'the closed border period' because it was only possible to cross it based on special passes. In January 1972, the border between Poland and the then German Democratic Republic was opened for free travel for residents of both countries. On October 30,1980, the German authorities closed the border again. The reason was the Solidarity Movement in Poland and fears of spreading the ideas of freedom on East German territory. Since then, the border could not be crossed without officially confirmed invitations. The border was reopened after the political changes in 1989. These changes, including the fall of the Berlin Wall, symbolically regarded as the end of the communist bloc, affected almost all of Europe. In November 1990, the Polish-German border treaty was signed, which sanctioned the functioning of the border in its current form. This enabled the development of cooperation between the twin cities, which introduced visa-free traffic and preparations for the foundation of the Pro Europa Viadrina Euroregion. However, the 1990s were still a period of repeated border tensions. For example, the dormitory of the Viadrina University in Frankfurt was set on fire as a protest against the increasing number of students from Poland (Asher 2012: 500). Ambiguous emotions accompanied the period immediately preceding Poland's accession to the European Union and the Schengen Area, resulting in fears of crime by Poles and stoking right-wing sentiments in Germany (Barthel 2020: 3; Jańczak 2018: 521). After 2007, when Poland joined the Schengen Area, twin cities like Frankurt-Słubice or Gubin-Guben became crucial from the perspective of the success of the Europeanisation project (Asher 2012: 501).

The transformations of the border reflected in the development of Polish and German sociological research on the borderland. Examples of research topics include identity issues (Machaj 2005), borderland social problems (Kurzępa 2007), research on twin cities (Schultz 2005), borderland during the Polish political transformation of 
the 1990s (Osękowski \& Szczegóła 1999). After 2007, the changing border landscape has become more closely studied due to increased mobility and the removal of formal controls (Kaczmarek 2010; Szlachcicowa 2019). Some researchers have even considered the twin cities as "laboratories of European integration". For example, Roose and Opiłowska were analysing how institutional activities (including creation of the Euroregions mentioned above) made it possible to realise the European Union's assumptions on cross-border cooperation and cultural exchange (2015).

One of the most recent research projects [De-Re-Bord. Socio-spatial transformations in German-Polish 'interstices'. Practices of debordering and rebordering] on this subject focuses on the socio-spatial transformations after 2007. The project adopts a processual understanding of the border. This means that changes in the functioning of the border are a constant phenomenon and that they can have two manifestations. Diminishing of the border and the facilitation of flows (debordering) on the one hand, and its sealing and strengthening (rebordering) on the other (Newman 2006: 180). Such changes are perpetuated not only on political, legal, and identity dimensions, but also on the landscape and everyday people's habits and experiences.

In the first stages of the project, several aspects of rebordering and debordering processes in Polish-German twin cities were identified. The process of debordering concerns such matters as the removal of border controls, the free movement of people across the border, the use of services by residents on the other side of the border, mutual contacts on both institutional and bottom-up levels. Shopping and consumption are critical here, but such activities include also living, working, and studying in a foreign part of twin cities and cross-border recreation. There are also institutional initiatives aimed at partnership (pupils mutual visits to schools, joint sessions of the Town Councils, police and border guard cooperation). At the same time, rebordering processes can be observed, what is especially visible at the economic level because of using different currencies in both countries. This is reinforced by cultural and linguistic differences and occasional border controls within the territory of both countries. Actual and imagined differences are reproduced, for example, through consumption. On the Polish side, one buys vegetables, cigarettes, alcohol, fuel or cheaper sweets and fizzy drinks, while on the German side of the border, one buys household chemicals or electronics. Describing these patterns, Asher points out that the type of products bought by Poles and Germans on both sides of the border reconstructs the ethnicity and hierarchy in the Frankfurt-Słubice twin city (Asher 2005: 133-136). Germany is imagined by buyers from both sides of the border as a country that produces high-quality, technologically demanding products and places higher taxes on goods that are harmful to health and the environment. At the same time, Poland appears as a country where fewer chemicals are used in the production of vegetables or cold cuts and a more deregulated place when it comes to the consumption of harmful goods.

The institutional debordering of the Polish-German border was suddenly suppressed and reversed because of the COVID-19 pandemic. Poland was one of the first EU states to close its borders on March 15, 2020. Controls, barricades, containers, and tents appeared at the border crossings with Germany. Those who wanted to enter Polish territory had to undergo a fourteen-day quarantine. This also affected Poles work- 
ing on the German side, who could no longer freely cross the border. Only those Polish citizens who remained on the German side could continue their work. These restrictions were lifted on May 4, 2020. The final reopening of the border and the abolition of controls took place on June 13, 2020. Meanwhile, the COVID-19 pandemic caused an unprecedented situation on the Polish-German borderland. It was an institutional decision that led to blocking movement and flows, changes in everyday practices, ways of understanding the border, and the sense of place of ordinary inhabitants of borderlands.

\section{METHODS}

Within border studies, the social processes of everyday debordering and rebordering are becoming more important than the border described only from the perspective of formal, international relations (Jensen 2013). Border studies have emphasised the role of non-state actors-individual residents, NGOs, entrepreneurs-in creating the principles of functioning and understanding borders (Cassidy et al. 2018). This paper draws attention to the specific dimension of these actors' border practice: border talks. These are bottom-up narratives about the border, reconstructed during everyday conversations of border residents (Doevenspeck 2011). Such practices are co-produced by public discourses which frames the ways of understanding the border and their consequences for the life of borderlands' inhabitants. They also structure the experience of the residents and thus produce common local knowledge.

Reference to Doevenspeck's concept, although initially developed for the analysis of the bottom-up construction of the Congolese-Rwandan border, seems to be inspiring for two other reasons when analysing European twin cities. The dynamics of ordinary people's conversations analysed by Doevenspeck was characteristic also for the Polish-German borderland. They referred to the dangers but also the benefits drawn from the Other, and they combined bottom-up experiences and sensory perceptions with the residuals of the media discourse on political and national differences. The pandemic also fostered border talks. German-Polish border closure affected the flows through it and thus the everyday practices of the inhabitants of the twin cities. The border once again became a focal point of interest because its previous, taken-for-granted functioning was questioned. In this way, the reality of the everyday life of the inhabitants of the twin cities was also disrupted. The pandemic has thus reframed the functions of the border in everyday life, intensifying thinking and conversations about it.

Between March 24 and May 11, when the Polish-German border was still closed, we conducted thirteen individual semi-structured interviews with the inhabitants of the Polish part of Gubin-Guben and Frankfurt-Słubice twin cities and their surrounding areas. Because of the lockdown, the interviews were conducted via phone (Irvine 2011). The interviews were conducted with participants who had taken part in the earlier stages of the De-Re-Bord project. Among the respondents were inhabitants diverse in terms of: gender (seven women, six men); age (the youngest interviewee was about 20 and the oldest 70 years old); place and type of residence (seven from 
the Słubice area, five from Gubin area, one from Poznań; ten from urban areas, three from rural areas); occupation (e.g. a porter, a library worker, a truck driver, as well as four experts: presidents of local merchant and community organisations, journalist, director of cultural institution).

The interview scenario addressed four main issues: recognising the changes in the functioning of the border caused by pandemic border closure, their evaluation, expectations toward their long-term consequences for cross-border cooperation, understanding the border (in the context of pandemic experiences). The more important parts of the interviews have been transcribed and coded according to the topics covered by the interview using a MAXQDA software. The empirical data was analysed using the typological method.

\section{RESULTS}

The Polish-German border's closure due to the COVID-19 pandemic was noticed in everyday life of borderland inhabitants in the four main areas. They concern different aspects of bordering practices: how border space is experienced during COVID-19 restrictions; what activities can be carried out there (work/education, household duties or self-fulfilment); reactions to border closures; and knowledge and understanding of the border's importance and roles.

\section{'An empty bridge looks terrifying'-an unusual border experience}

As a result of the reduction of border traffic, the local landscape changed, creating a surreal experience for people living close by. The reasons were both the suspension of the everyday life rules and obviousness (as a result border closure and the accompanying changes in the functioning of the individuals and local community), but also the anxiety and fear caused by the prospect of losing one's job or health because of the pandemic.

An important dimension of the local landscape became the elements associated with the state of emergency: the police cars placed along the borders and controls carried out by people in protective clothing. Many residents mentioned specific soundscape: pervasive silence in the city, the noise of wandering people, their suitcases knocking on pavements, the lack of a so far widespread German language, or announcements made from police cars. On the one hand, the residents evoked images of huge traffic jams after announcing that the borders would be closed. On the other hand, a shared experience of the emptiness appeared just a few days later, which concerned empty bridges and other, so far busy places: 'There were remarks that everything is allowed at the bazaar ${ }^{1}$. When something stopped functioning in the city, the orchestra was still playing [on the bazaar], like the Titanic. But necessarily, when the customers stopped coming, the bazaar stopped functioning' [ID22].

The interviews bring back memories about people returning to Poland from other countries, who landed in Berlin and tried to cross the border in Słubice: 'It was a bit

\footnotetext{
${ }^{1}$ The interviewee talks about Bazaar Europa, the biggest market place in Słubice.
} 
like an airport in the city because many people were moving around the city with their suitcases. They also had trouble getting taxis, some in hotels, someone was picking them up' [ID22].

The experience of this change was intensified by confusion-uncertainty about the rules of crossing the border, changing every few days:

These government decisions were made very quickly, and a lot was happening [...]. It was unclear what these decisions would be like, whether these borders would be closed, what now with work. Many people had to move there not to cross the border; it is already a publicised topic that families were separated, mothers or fathers sometimes had to leave their children, sometimes they both work abroad [ID24].

The experienced situation combined emotions and memory, bringing back memories from the past (Opiłowska 2014), when the border was closed during the cold war: 'We are locked in. Closed around us, as it used to be during the communist era'. [ID29]. The possibility of the free border crossing was one of the key features that inhabitants perceived of the systemic and (geo)political changes of the last 30 years.

\section{‘There are no Germans, and there is just a catastrophe'-problematic actions}

Border closure had an impact on the possibility of earning money. In the first weeks, the restrictions threatened to quarantine all Poles working in the German border area. This forced either multi-day breaks in work or temporary residence on the German side: 'Some people start to run out of bread, so much has changed, because if somebody worked on the German side and cannot work overnight, problems start [...]. If somebody comes to me to chop up trees because there is no bread' [ID12]. The expanded sector of cross-border services such as hairdressers, beauticians, dentists was also deprived of income.

The specificity of twin cities is to fulfil different life needs on both sides of the border. Polish children often go to German schools. Polish residents have a registered business activity in Germany and use leisure activity infrastructure. After closing the border, access to many necessary services and goods was restricted. Likewise, institutional cross-border initiatives such as the Hanseatic League Day and the Frankfurt and Słubice city council meetings were suspended. The resident mentions that 'the twin city model, promoted for years, has failed' [ID11].

Such a collapse of the previous actions resulted in creating new activities and forms of cooperation. German employers helped their Polish employees with temporary accommodations in the German borderland and organised additional border transport. The border bridge in Słubice served as a place for handing over various things. The residents recalled how Polish veterinarians handed over medicines for German animal owners. However, the authorities banned these practices because they became abused: medication and cigarettes were exchanged. Drivers began to play the role of intermediaries in Polish-German social and shopping relations, as they could cross the border without quarantine. As we learn from the wife of one of them: 'Such requests 
are common, we are already sick and tired of them. If it is important, everyone wants to help. However, if we are supposed to be, well, a middleman for people's shopping, it becomes a bit of a nuisance' [ID24].

'German restaurants are open until 6:00 pm as if you cannot get infected at 5:30 pm'-the attitude to the closure of the border

The decision to close the border resulted in various reactions. Some people strongly supported this decision:

There was a bit of a narrative "the virus is from the West, from abroad", which fits very well into the narrative of the Polish government [...]. There were such voices that we in Poland will succeed. We need to cut ourselves off from all this evil, a leftist virus of corruption [ID22].

Others pointed out the costs of this situation for the local economy and called for less strict regulations. One of the residents pointed at the differences between Polish and German standards of coping with the pandemic:

I am delighted they closed the border to foreigners because now I see that many people from Germany visited Słubice, and I can see what kind of behaviour and attitude they have towards this situation-they do not care at all [ID35].

The residents have differed in evaluating detailed regulations, but they were unanimous and critical of their effectiveness. Some statements point out that there was much powerlessness in the act of closing the borders. They defined the situation as an expression of a lack of actual control or even a political spectacle. Others pointed out that further necessary actions did not follow the decision to close the borders: 'The people who were obliged to be in quarantine after crossing the border were walking around Słubice, shopping [...]. They were mixing among themselves. A failure, a tragedy! The organisation was terrible' [ID35].

Different attitudes towards the closure and restriction of border traffic resulted in protests. The Mayor of Słubice, under pressure from Słubice’s inhabitants, appealed to the Lubuskie Voivodship Governor to close the border entirely. Poles working on the German side of the border also protested. Some of the protests were of a more symbolic and performative character, e.g., walking on the embankment or hanging banners: 'The most effective way of protesting was a banner on the bridge in Słubice-“Open the border, we will survive together"-something like that' [ID27].

\section{'That is why we have the European Union-so that there are no borders'-reflection on borderline}

A reflection has accompanied the change of the landscape and practices on the border as a line dividing two countries and legal systems. The residents mentioned that they started to feel the border again: 'Everyone realised. Older groups remembered, and youngsters realised that something like this once existed and that the border has brought many topics throughout history' [ID11]. 
The border emphasised experiencing cultural differences between Poles and Germans during the pandemic, such as using remote contact and teaching technologies in schools. The initial lack of understanding of German employers for Polish restrictions and even for differences in culinary habits was indicated:

Imagine, you have worked all year round, hired 20 people, made 20 hectares of asparagus and today there is no one to buy it - this is some kind of joke [...]. Those who have a garden market here at the border, if they cannot sell it here, will not sell it at all (to Polish customers). First, it is a bit expensive. Second, we are not taught to do certain things. The Germans eat it every day, and we do not see it on the tables like [ID12].

Some of the residents mentioned differences in the approach to the pandemic itself-more reckless in Germany and more responsible in Poland:

When the Germans saw me walking into the hall with my gloves on and my jacket on my face, they knocked themselves on the head like I was crazy [...]. I talked to a guy three weeks ago, and now he will not look straight into my eyes. I told him: "Watch out because everyone thought they would be okay. The Italians, the Chinese... You are still well because you are a rich country and you have better health care than us. Better hospitals, more doctors, but also more people”. They are idiots, believe me. A guy walks through the room and sings: "Coronavirus, coronavirus!" [ID 35].

This type of argumentation fits into the general framework of thinking about Polish-German relations. Poles like to stress that Germans can afford a 'carefree attitude' due to their higher level of development. In contrast, Poles are more 'resourceful and disciplined' because they have to. We can interpret that as another example that the pandemic and its aftermath reinforced rather than modified previous attitudes and perceptions towards German-Polish relations. The resourcefulness of Poles implied in the quotation had also been raised earlier, for example, shortly before Poland's accession to the Schengen Area, when the alleged resourcefulness and initiative of Poles was seen as an opportunity for the declining German post-industrial border cities. Polish entrepreneurship was then characterised by a younger and more mobile workforce and smaller in size and employment that were supposed to support the transformation of the declining economic monocultures of East German cities (see, i.e. Matthiesen 2005).

\section{DISCUSSION}

Several findings emerge from our research. First, the COVID-19 pandemic, the period of lockdown, and restrictions on border traffic significantly changed the lives of border residents. It has become challenging, if not impossible, to carry out everyday practices that are dependent on the border, such as shopping, recreation, work, and study on the other side of the border, providing services to the inhabitants of the other side. Not only inhabitants' situation but also place image and borderland identity (an essential part of which is the feeling of being part not so much of the periphery as of the cen- 
tre of a cosmopolitan project of EU integration) have been disturbed. Emptiness and dismissal were present in the borderland and all the areas affected by the restrictions related to COVID-19. At the same time, in the statements of the borderland residents, one can see a desire to point out the specificity of their experience in this area - the atmosphere of a place without cross-border flows. This may be the way to maintain their identity as a borderland inhabitant during a closed border period.

Second, the pandemic was a time for articulating differences between Poland and Germany. On the individual level, it revealed the way of thinking about 'resourceful' Poles who can fight the virus and 'carefree' Germans who are quite loosely approaching the resulting threat. On an institutional level, it underlined the differences in the regulations for dealing with the pandemic as an epidemiological threat. The lack of parallel regulations resulted in the inhabitants' perception of the lack of control over the hitherto unknown, invisible threat. As we heard, this was also a reason for stigmatising ones who maintained too close relations with those on the other side of the border.

Third, the time of the closed border revealed its fundamental economic significance for both sides. On the one hand, Poles who worked on the German side could not freely cross the border. Only by staying in Germany could they continue to work, while those who crossed the border every day had no such possibility. This concerns many people because it is estimated that about 70,000 Poles travel to work in Germany every day (Bilger 2020). On the other hand, closing the border was a significant inconvenience for the Germans, who used cheaper purchases and services on the Polish side. After opening the border, this was even the subject of a 'survey' conducted by the 'Nordkurier' daily newspaper. The question was what the respondents were most happy about after the opening of the Polish-German border. Most people (42.1\%) answered that from the possibility of buying cigarettes on the Polish side, $22 \%$ from holidays in Poland, $9.3 \%$ from the opportunity to see the family, and $7.7 \%$ from cheap petrol (Bahr 2020).

Fourth, the time of the pandemic did not significantly change residents' perceptions and expectations of the border. When asked about normality after the pandemic, Polish borderland residents advocated a return to the situation before COVID-19. If there were any changes in the border crossing regulations, it was only in future harmonising standards of dealing with similar situations. The paradoxical consequence of closing borders would be to realise that more important than controlling border traffic is a shared culture of restrictions. Such culture allows the coordination of actions at an institutional level and similar compliance patterns with restrictions on both sides of the border. This would be particularly important for twin cities, which further development as interdependent hubs depends, it now seems to us, on the development of more elaborate strategies than physically dividing them from one day to the next.

Fifth, the pandemic period has shown the existing processes of debordering and rebordering excitingly. The rebordering process was present at that time, primarily on an institutionalised level. State and local authority activities aim to tighten cross-border flows restrictions while maintaining cooperation at the symbolic level, e.g., logos or remote ritual meetings. The inhabitants' attitudes aimed to seek new, informal 
ways of sustaining the flows: the transfer of goods across the border, the transport of parcels by drivers, symbolic protests against restrictions. This can be seen as seeking new forms of internalising and embodying relations and practices for sustaining international mobility which is fundamental to these places' daily functioning and identity. This situation revealed a rare process in which debordering occurred at the micro-level and its reproduction at the mezzo- and macro-level. Contemporary research shows that these processes are oppositely taking place (Schroer 2009). At the same time, our research confirms that the bottom-up processes of debordering, rather than the desire to maintain Polish-German relations at the social bond level, are directed towards the border as a resource (allowing contact, promoting differentials, hybridisation, symbolic resource; Sohn 2014b).

For our study was exploratory, the attempt to generalise the collected data and conclusions has its limitations. It was conducted quite spontaneously at the very beginning of the COVID-19 pandemic in 2020. We decided to interview our previous interviewees for two reasons. First, we were convinced that we were dealing with a unique situation, and it was almost the duty of social scientists to understand it. Thus, it became possible to identify several dimensions of border residents' reactions to the situation of pandemics and border closure. Second, we treated the situation as a breakdown in the everyday lives of the inhabitants of the twin cities. The realisation of many daily activities-both professional and leisure-became impossible. This resulted in the intensification of border talks: the desire to share one's fears, problems, and emotions. For a good reason, however, they are primarily concerned with everyday life in the twin cities: the landscape, the undertaken activities, the perception of the immediate future. That is why we do not deepen the economic and geopolitical context in our analyses. At the same time, we recognise the need to include them in a furthermore in-depth studies of the consequences that the pandemic have and will have for border areas and their inhabitants.

FUNDING: This work was supported by the Polish National Science Centre under Grant UMO-2016/23/G/HS6/04021 (project 'De-Re-Bord. Socio-spatial transformations in German-Polish “interstices”. Practices of debordering and rebordering').

CONFLICT OF INTEREST: The authors declare no conflict of interest.

ACKNOWLEDGEMENTS: The first version of this paper was writen by Maciej Frąckowiak, Łukasz Rogowski and Professor Jerzy Kaczmarek. Prof. Kaczmarek was also the Primary Investigator of the Polish part of the De-Re-Bord project. He passed away in April 2021. Maciej Frąckowiak and Łukasz Rogowski would like to thank prof. Kaczmarek for the friendship and cooperation. We hope this paper will spread his work and perspective on borderland studies.

The authors of the article would like to thank the research participants for taking the time to share their experience during this difficult pandemic period, and the reviewers for their helpful comments and suggestion for improvement. We also thank Przemysław Rura and Natasza Doiczman-Łoboda, members of the De-Re-Bord team, who helped to conduct the interviews analysed in the paper. 


\section{REFERENCES}

Asher, Andrew D. "A Paradise on the Oder? ethnicity, europeanization, and the EU referendum in a Polish-German border city.” City \& Society 12(1): 127-152.

Asher, Andrew D. 2012. "Inventing a city: cultural citizenship in 'Słubfurt." Social Identities: Journal for the Study of Race, Nation and Culture 8(5): 497-520. https:// doi.org/10.1080/13504630.2012.667601

Bahr, Gerald. 2020. "Darum wollen Deutsche wieder sofort nach Polen.” Nordkurier, 11 June, https://www.nordkurier.de/mecklenburg-vorpommern/darum-wollendeutsche-wieder-sofort-nach-polen-1139660106.html [03 September 2021].

Barthel, Martin. 2020. "Capricious pathways - a comparative analysis of local identity building in border regions. A case study of Polands Western and Eastern border.” Belgeo Revue belge de géographie 2: 1-12. https://doi.org/10.4000/belgeo.38736

Bærenholdt, JO. 2013. “Governmobility: The Powers of Mobility.” Mobilities 8: 20-34. https://doi.org/10.1080/17450101.2012.747754

Berger, Peter L. \& Thomas Luckmann. 1966. The social construction of reality: A treatise in the sociology of knowledge. New York: Penguin Books.

Bilger, Oliver. 2020. "Pendler protestieren an der polnischen Grenze <<Wir wollen nicht, dass unser Leben in zwei Stücke gerissen wird>>.” Der Tagesspiegel, 29 April, https://www.tagesspiegel.de/themen/reportage/pendler-protestieren-ander-polnischen-grenze-wir-wollen-nicht-dass-unser-leben-in-zwei-stueckegerissen-wird/25783824.html [03 September 2021].

Cassidy, Kathryn, Nira Yuval-Davis, and Georgie Wemyss. 2018. “Debordering and everyday (re)bordering in and of Dover: Post-borderland borderscapes." Political Geography 66: 171-179. https://doi.org/10.1016/j.polgeo.2017.04.005

Doevenspeck, Martin. 2011. "Constructing the border from below: Narratives from the Congolese-Rwandan state boundary.” Political Geography 30: 129-142. https:// doi.org/10.1016/j.polgeo.2011.03.003

Eurofund. 2020. Living, working and Covid-19: First findings, https://www.eurofound. europa.eu/publications/report/2020/living-working-and-covid-19-first-findings-april-2020 [03 September 2021].

Haselsberger, Beatrix. 2014. “Decoding borders. Appreciating border impacts on space and people.” Planning Theory and Practice 15: 505-526. https://doi.org/10.1080/1 4649357.2014.963652

Irvine, Annie. 2011. “Duration, Dominance and Depth in Telephone and Face-to-Face Interviews: A Comparative Exploration.” International Journal of Qualitative Methods 10(3): 202-220. https://doi.org/10.1177/160940691101000302

Jańczak, Jarosław. 2018. "Symmetries, asymmetries and cross-border cooperation on the German-Polish border. Towards a new model of (de)bordering." Documents d'Anąlisi Geografica 64(3): 509-527. https://doi.org/10.5565/rev/dag.518

Jensen, Anne. 2013. "Mobility Regimes and Borderwork in the European Community." Mobilities 8: 35-51. https://doi.org/10.1080/17450101.2012.747780

Joennieni, Pertti. 2016. "Others as Selves, Selves as Others: Theorizing City-Twinning.” Journal of Borderlands Studies 32(4): 1-14. https://doi.org10.1080/088656 
55.2016 .1260040

Kaczmarek, Jerzy. 2001. "Euromiasto Gubin-Guben-model zjednoczonej Europy?” Pp. 369-378 in Transgraniczność w perspektywie socjologicznej. Kontynuacje i wyzwania. Zielona Góra: Lubuskie Towarzystwo Naukowe.

Kaczmarek, Jerzy. 2010. "Badania wizualne pogranicza polsko-niemieckiego.” Ruch Prawniczy, Ekonomiczny i Socjologiczny 72: 203-216.

Kurzępa, Jacek. 2007. Socjopatologia pogranicza. Zmiany w życiu społeczności zachodniego pogranicza. Studium socjologiczne. Zielona Góra: Oficyna Wydawnicza Uniwersytetu Zielonogórskiego.

Machaj, Irena. 2005. Społeczno-kulturowe konteksty tożsamości mieszkańców wschodniego i zachodniego pogranicza Polski. Warszawa: Wydawnictwo Naukowe Scholar.

Matthiesen, Ulf. 2015. “Governance Milieus in Shrinking Post-Socialist City Regionsand their Respective Forms of Creativity: Case Miniatures and Conceptual Propositions." disP - The Planning Review 162(3): 53-61. http://dx.doi.org/10.1080/02 513625.2005.10556932

Newman, David. 2006. "Borders and Bordering Towards an Interdisciplinary Dialogue." European Journal of Social Theory 9(2): 171-186. https://doi. org/10.1177/1368431006063331

Opiłowska, Elżbieta. 2014. “The Miracle on the Oder.” East Central Europe 41(2-3): 204-222 https://10.1163/18763308-04103003

Osękowski, Czesław \& Hieronim Szczegóła. 1999. Pogranicze polsko-niemieckie w okresie transformacji (1989-1997). Zielona Góra: WSP.

Parker, Noel \& Nick Vaughan-Williams. 2009. "Lines in the Sand? Towards an Agenda for Critical Border Studies.” Geopolitics 14: 582-587. https://doi. org/10.1080/14650040903081297

Roose, Jochen \& Elżbieta Opiłowska. 2015. “Introduction.” Pp. 7-15 in Microcosm of European Integration: The German-Polish Border Regions in Transformation. Baden-Baden: Nomos Verlagsgesellschaft.

Schroer, Markus. 2009. “Grenzen in Bewegung.” Powision. Magazin am Institut für Politikwissenschaft 1: 64-65.

Schultz, Helga. 2005. "Doppelstädte als Laboratorien der Integration.” Pp. 13-26 in Stadt - Grenze - Fluss. Europäische Doppelstädte. Berlin: Berliner Wissenschafts-Verlag.

Szlachcicowa, Irena. 2019. "Borderscapes - krajobrazy granic jako nowa perspektywa badan.” Politeja 58: 15-29. https://doi.org/10.12797/Politeja.16.2019.58.02

Scuzzarello, Sarah \& Catarina Kinnavall. 2013. "Rebordering France and Denmark. Narratives and Practices of Border-Construction in Two European Countries." Mobilities 8: 90-106. https://doi.org/10.1080/17450101.2012.747775

Sohn, Christophe. 2014a. "Modelling Cross-Border Integration: The Role of Borders as a Resource.” Geopolitics 19: 587-608. https://doi.org/10.1080/14650045.2014 .913029

Sohn, Christopne. 2014b. "The Border as a Resource in the Global Urban Space: A Contribution to the Cross-border Metropolis Hypothesis." International Journal of Urban and Regional Research 38: 1697-1711. https://doi.org/10.1111/1468- 
2427.12071.

\section{BIOGRAPHICAL NOTE}

Maciej Frąckowiak - sociologist, assistant professor at the Faculty of Sociology, Adam Mickiewicz University in Poznań and lecturer at Design Department, SWPS University in Warsaw. He is interested in urban sociology, sociology of architecture and urban planning, visual research, and sociology of culture. He participated in many research projects concerning architecture, culture, and border studies. He currently participates in international research project: 'De-Re-Bord' (where he researches Polish-German borderland). ORCiD: 0000-0003-3802-1184.

Jerzy Kaczmarek - professor at the Faculty of Sociology, Adam Mickiewicz University in Poznań. Research interests: history of sociology and social thought, sociology of borderland, sociology of art, visual sociology, post-secularism. Head of the international research project 'De-Re-Bord', focusing on the study of the Polish-German borderland. ORCiD: 0000-0001-8314-199X.

Łukasz Rogowski - sociologist, assistant professor at the Faculty of Sociology, Adam Mickiewicz University in Poznań. He is interested in visual sociology, visual research, ethics of qualitative research, sociology of mobilities, sociology of new media. He participated in many research projects focused on, among others, urban visual culture, visual competence, social usage of smartphones and mobile applications. He currently participates in two international research projects: 'De-Re-Bord' (where he researches Polish-German borderland) and 'Ruraction' (Horizon 2020 project, where he is an ethical commissioner and coordinator of visual research). ORCiD: 0000-0001-6090-8975.

OPEN ACCESS: This article is distributed under the terms of the Creative Commons Attribution Non-commercial License (CC BY-NC 4.0) which permits any non-commercial use, and reproduction in any medium, provided the original author(s) and source are credited.

ARTICLE HISTORY: Received 2021-09-03 / Accepted 2021-12-08 